\title{
Can Norway Be a Role Model for Natural Resource Abundant Countries?
}

\author{
Ådne Cappelen ${ }^{1}$ and Lars Mjøset ${ }^{2}$
}

April 2009

\begin{abstract}
During the 1950-70s Norway had relatively low GDP per capita compared to the OECD average and even more so compared to Denmark and Sweden. During the 1970s there was a significant catch-up in incomes and from the early 1990s a 'take-off' in relative income. Norway is currently ranked among the countries with the highest GDP per capita in the world and is at the top according to UNDP's human development indicator. We argue that this development is related to the growth of the Norwegian petroleum sector, although many studies of economic growth conclude that countries abundant in natural resources are not blessed but cursed by gifts of nature. How has Norway avoided so many of the possible problems that follow in the wake of a natural resource-based development? Nowadays the standard answer to this question is 'good institutions' and 'clever policies'. In this paper we detail the institutions and policies that may explain the peculiar development success of Norway. There are lessons here that can contribute to policy learning, but only on the provision that the specificities of the 'learning' country are understood.
\end{abstract}

Keywords: cross-section models, economic development, natural resources, resource booms

JEL classification: C21, C22, O1, O4, O5, O10, O13, Q33

Copyright @ C UNU-WIDER 2009

${ }^{1}$ (corresponding author) Research Department, Statistics Norway, email: cap@ssbno; 2 Department of Sociology and Human Geography, University of Oslo, Lars.mjoset@sosiologi.uio.no

This study has been prepared within the UNU-WIDER project on Country Role Models for Development Success, directed by Augustin Kwasi Fosu.

UNU-WIDER gratefully acknowledges the financial contributions to the project by the Finnish Ministry for Foreign Affairs, and the financial contributions to the research programme by the governments of Denmark (Royal Ministry of Foreign Affairs), Finland (Finnish Ministry for Foreign Affairs), Norway (Royal Ministry of Foreign Affairs), Sweden (Swedish International Development Cooperation AgencySida) and the United Kingdom (Department for International Development). 


\section{Acronyms}

HDI human development indicator

NICs newly industrialized countries

The World Institute for Development Economics Research (WIDER) was established by the United Nations University (UNU) as its first research and training centre and started work in Helsinki, Finland in 1985. The Institute undertakes applied research and policy analysis on structural changes affecting the developing and transitional economies, provides a forum for the advocacy of policies leading to robust, equitable and environmentally sustainable growth, and promotes capacity strengthening and training in the field of economic and social policy making. Work is carried out by staff researchers and visiting scholars in Helsinki and through networks of collaborating scholars and institutions around the world.

www.wider.unu.edu

publications@wider.unu.edu

UNU World Institute for Development Economics Research (UNU-WIDER)

Katajanokanlaituri 6 B, 00160 Helsinki, Finland

Typescript prepared by Liisa Roponen at UNU-WIDER

The views expressed in this publication are those of the author(s). Publication does not imply endorsement by the Institute or the United Nations University, nor by the programme/project sponsors, of any of the views expressed. 


\section{Introduction}

Norway is a small open economy at the periphery of Europe. It is often claimed that together with the other Nordic countries (Denmark, Finland, Iceland and Sweden), Norway represents an alternative model of economic and social development compared both to the continental European model and an Anglo-American model. 1 The main reason for the interest in the Nordic (or Swedish) model is the ability of these countries to combine a relatively high level of income with an equal income distribution and social security involving a large public sector financed by high taxes. The explanation of how these countries are able to achieve these goals requires comparative analysis, so that common features can be judged with reference to national peculiarities. Our analysis focuses mainly on Norway. 2 Since the late 1960s, Norway has become increasingly different from the other Nordic countries. Norway is the only Nordic country with a recent history of renewed resource wealth. Thus, we mainly analyse the challenges of including a large petroleum sector in the Norwegian economy, emphasizing parallels in earlier Norwegian economic history. This focus should be of interest to the study of the Nordic model as well, since the Norwegian experience may tell us something about the robustness of the Nordic model to external shocks.

We argue that Norway has avoided the resource curse for several reasons. First, Norway had a history of natural resource management that included integrating natural resource-based industries with the rest of the economy through various linkages. Second, institutions were developed to handle shocks to the economy that are endemic to resource productions such as large changes in terms of trade. Also the separation of rents based on natural resource extraction from spending these rents, has gradually led to the establishment of a buffer fund that helps to create a more stable economic environment. Finally, the real returns from a large financial fund (currently roughly equal to GDP) help to finance public expenditures with less deadweight loss than before. This potential efficiency effect of resource abundance has not received much attention in the literature.

Section 2 discusses some principal problems concerning policy learning with reference to the Norwegian case. Section 3 is a small portrait of the Norwegian economic history, and section 4 surveys recent Norwegian economic policies. Section 5 surveys the parts

1 The notion of a model deserves some comments: There is a notion of the Swedish model which can at least partly be modelled in terms of equations, that is, the way economists traditionally understand models. The notion of a model employed here, however, is linked to the phenomenon of certain paradigmatic cases that rise to fame in discussions about economic policies and development strategies. The term model here signals possible relevance for policy learning (as in the even more explicit term 'role model'). In some fields of social science, and particularly in the area of welfare state studies, more extensive typologies are available. The distinction between Nordic, continentalEuropean and Anglo-American models is well established (Esping-Andersen 1999). In the following, our notion of a model is that of a model of economic development. The study of such models can draw on a number of typological efforts in the analysis of various institutional spheres (finance, corporate governance, inter-firm relations, industrial relations, systems of skill creation, work organization, welfare state) which constitute the specificities of modern national economies. For such an approach to varieties of capitalism, see Mjøset and Clausen (2007). Such an approach can be considered an alternative to the programme of Hall and Soskice (2001). An in-between classification (actually the threefold welfare state distinction in which the Nordic countries are one out of three groups) is used in Pontusson (2005).

2 For comparisons with the other Nordic countries, cf., Mjøset (1987) and (2006). 
of the resource curse and Dutch disease literatures that are often claimed to be highly relevant to the Norwegian case. Section 6 presents an alternative view of the connections between natural resources and economic development, while section 7 discusses some growth regressions that have recently been presented to support the resource curse position. Section 8 concludes.

\section{The question of policy learning}

Whether Norway is a relevant case for policy learning depends on what kinds of units we believe are supposed to learn. Mostly, these units will be some kind of states, but it matters a lot what kind of states. Given that we need a rough typology of states, we need to turn to development studies. ${ }^{3}$ First, we may distinguish early starters and latecomers. Roughly, most of present-day OECD countries were early starters, on the track of industrialization before the late nineteenth century. At that time, the last big wave of colonization occurred and improved transport technologies and infrastructures opened up the resources (raw materials and foodstuffs) of the non-industrialized world for utilization by industrialism's early starters. However, the economic, social and cultural structures affected by this extension of world economic circuits were quite diverse. Kasa and Mjøset (2001) distinguish four types:

1) Westernized settler colonies (such as the US, Australia, and New Zealand),

2) 'Self-colonized' states (most Latin American states),

3) Colonized plantation economies (many Asian cases), and

4) Colonized peasant economies (especially Sub-Saharan Africa).

A fifth type (5) could be added, covering the Arab economies, many of which started to explore oil-resources in the semi-colonized setting of the Anglo-French mandate system in the first half of the twentieth century.

Another distinction is the extent to which these political units were allowed to pursue institutional developments that responded to local conflict lines, or whether institutional development was decisively influenced by colonization. Especially significant are the Asian cases of Japan and China, wholly or partially escaping colonial dominance. Interestingly, Japan became the paradigm case of the development state (Evans 1995), a notion used later to analyse the postwar success of the newly industrialized countries (NICs) and intra-OECD latecomer/catch-up cases (such as Ireland and Finland). The issue of policy learning is basically whether some of the latecomers (types (2) to (5) above) had the capacities to move into position as development states (cf., earlier notions of 'threshold economies' and even earlier, 'take-off' economies).

The economic theories we discuss in section 5 deal with the relationship between natural resources and economic development. They apply highly formal theory indiscriminately to all cases. But the actual processes observed by economic historians depend on the context. With reference to the rough typology above, we can make the

3 The following is drawn from a more detailed study: Mjøset (2006). See also Evans (1995) and Evans and Rauch (1999). 
following specification: most of the earlier colonized (both plantation and peasant) economies are today postcolonial economies. The challenges they face in terms of development are largely the long-term consequences of having been turned into resource-providers to the richer world. Because of this, their institutional structure has been crucially influenced by the clash between autonomous institution-building and colonial legacies. These institutional frameworks are biased towards a pessimistic development scenario. One would need a more fine-grained typology to distinguish the potentials for cultivating preconditions of the developmental state.

The settler colonies in the new world largely succeeded in broad-based development, despite being raw materials suppliers to the old world. In this sense, they are parallel to the early starters of the nineteenth century 'European periphery' which included the Nordic countries, cf., Senghaas (1985). As for the second type, that of 'self-colonizing' economies, they were also settler colonies, but their success was less permanent than that of the type (1) countries. The ironic term 'self-colonized' refers to a set of more home-grown barriers to development, in particular related to the highly skewed distribution of agricultural land and a political system conserving these inequalities. These cases are found in Latin America, and Argentine is a particularly spectacular case. The type (5) states (Arab economies) are burdened by other 'weak state' problems.

In any dataset of nation states, type (2)-(5) cases dominate. The mainstream economic literature on resources and economic growth makes the general claim that countries with a large share of their production or exports based on natural resources grow less than most other countries. Typically many OPEC countries (mostly type (5)) have experienced even declining growth rates in per capita GDP for long periods of time. The resource curse is modelled as a basic, underlying process in any economy based on raw materials, cf., Sachs and Warner (2001) and Auty (2001).

In terms of per capita GDP growth, Norway's performance can be taken as a refutation of this general model. In conjunction with both the two cases of sudden discovery of exploitable energy resources that mark its twentieth century economic development, Norway enjoyed above average income. The development of water power for electricity generation in the early twentieth century led to an increase in relative income, as Norway was above the 12-country European average income level for 1913-50, and also above Sweden and Denmark; cf., Maddison (2003). With oil since the early 1970s, Norway gradually improved its relative income level and currently ranks among the richest countries in the world when measured by GDP per capita in PPPs, cf., Figure 1. It seems that Norway has experienced these two periods of catching up largely because of resource abundance, not in spite of its natural resource base! The last surge brought the country's income from below average to the world front in three decades of oil exploitation.

In that period, huge oil rents accrued to the national economy, which, through the postwar period, had become broadly developed within a stable political-institutional framework. In recent history there are probably few other cases of a small, developed economy gaining such a windfall. For this reason, the potential for policy learning from Norway's recent experience should not be exaggerated. However, a comparison between the 1913-50 period and the post-1970 period shows that the 'oil adventure' may be relevant for policy learning. Long before oil was discovered, the Norwegian economy had relied on raw materials exports, but had combined economic growth with an egalitarian distribution of income. In this respect, the Norwegian experience 
converges with a more general Nordic experience. During the period of nineteenth and early twentieth century industrialization, all the Nordic countries had major natural resources in their export baskets. Timber, fish, and some agricultural staples were traditional export items but since the late nineteenth century, resources became important also because of changes in production-, exploration- or transporttechnologies, most strikingly in the case of the above mentioned two Norwegian energy sources. This experience has been explored in interdisciplinary research cf., Senghaas (1985) and Mjøset (2007) for a broad survey. We return to this in section 3.

Efforts have been made to modify the resource curse argument in the light of such historical facts. One must then interpret the resource curse as an underlying process that may be counteracted. Mehlum, Moene and Torvik (2006) point to institutional qualities: Norway and a few other countries have been able to counteract the resource curse and the 'grabbing' or rent seeking activities that are usually associated with the curse. But according to this latter study, institutional quality has just been able to counteract the curse. The success - why has an oil dependent economy outperformed most other countries - is still to a large extent unexplained. 4 What, then, is really the key to success for countries with resource abundance? If on the other hand, we hold, as we tend to do, that petroleum production is perhaps the main reason for Norway having done so well since 1970, we need to explain why this has been the case.

Figure 1

GDP per capita, current PPP, 1970-2006

Denmark, Norway, Sweden $(\mathrm{OECD}=100)$

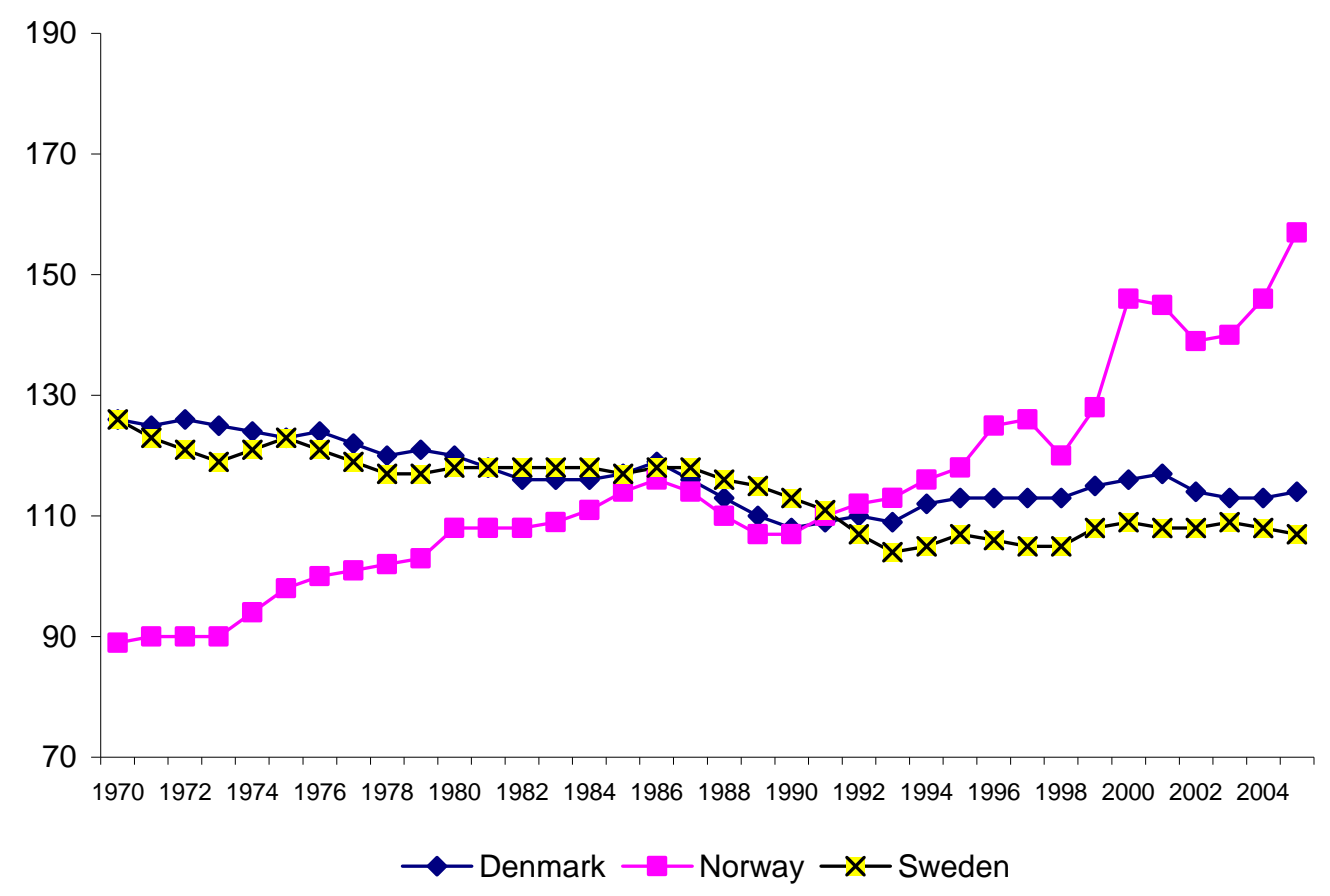

Source: OECD National Accounts 2008.

4 The difference is less striking in the 1913-50-period, but even then, Norway is above the western European and world averages (Maddison 2003). 
Table 1

Human development indicator relative to the US level, 1980-2006

\begin{tabular}{lllllll}
\hline & 1980 & 1985 & 1990 & 1995 & 2000 & 2006 \\
\hline Denmark & 0.988 & 0.982 & 0.976 & 0.982 & 0.992 & 1.002 \\
Norway & 1.009 & 1.006 & 1.004 & 1.016 & 1.017 & 1.019 \\
Sweden & 0.989 & 0.986 & 0.983 & 1.002 & 1.008 & 1.008 \\
\hline
\end{tabular}

Source: UNDP (2008).

It is not only in terms of economic development that Norway has performed well in recent decades. Using the UNDP's human development indicator (HDI) to show a broader perspective on social and economic development, Table 2 indicates that economic development with increasing GDP per capita is not the only area where the Scandinavian countries have been performing well for a long time. In Table 1 we use the US as the reference point so the figures are the national HDI levels divided by the US figure for the same year. 5 We see that all three Scandinavian countries have improved their HDI levels compared to the US since 1990 but did not do so well during the 1980s. It is worth noting that the HDI indicator caps GDP per capita at very high levels so the HDI level for Norway has not increased in recent years even if GDP has increased much as shown in Figure 1. In spite of this, the relative performance of Norway is quite impressive in terms of HDI.

\section{Main characteristics of the Norwegian economy-before and after oil}

Like in the other countries of the nineteenth century European periphery, economic development in Norway involved responses to impulses from the leading economy, Britain. Export incomes were secured through the traditional, pre-industrial export items such as salted or dried fish and timber. Traditionally, the Norwegians were skilled seamen and shipbuilders. As raw materials exports picked up, a shipping sector developed as a specific kind of backward linkage.6 Quite extraordinarily, by the 1880 s Norway had the world's third largest commercial shipping fleet. Norway was clearly very much integrated into the world economy already at this stage. In terms of providing export revenues, this implied that exports of services compensated, to a large extent, for the near-absence of a manufacturing sector producing tradable goods.

While lacking manufacturing exports, a pool of manufacturing skills developed in various economic sectors. These developed as experience with up-to-date technologies was applied to traditional resource-based economic activities. A number of backward

5 The data source is UNDP (2008: Table 1).

6 The notion of linkages was introduced by Hirschman (1958), and generalized with special reference to staple exports in Hirschman (1977). Linkage effects of a given product line are defined as 'investment-generating forces that are set in motion, through input-output relations, when productive facilities that supply inputs to that line or utilize its outputs are inadequate or nonexistent. Backward linkages lead to new investments in input-supplying facilities and forward linkages to investment in output-using facilities. The generalized definition starts from the characteristics of a country's productive activities in process at a certain time. These (...) push or, more modestly, invite some operators to take up new activities. Whenever this is the case, a linkage exists between the ongoing and the new activity'. 
and forward linkages can be traced. Related to shipping, there was improved shipbuilding, and the production of intermediate goods related to shipping transport. Related to the fisheries, there was whaling and canning. Related to the saw mills, there was, e.g., sawing equipment, leading to steam-driven equipment that was Norway's first manufacturing experience in the 1870s. In the 1890s, processes of copying and adaptation led to export production of pulp machinery (Lange 1989: 17).

While Norway's agricultural sector was largely based on natural economic self-reliance, there were extensive additional employment opportunities: inland smallholders would temporarily work in the forests, while those living in the coastal areas would participate in seasonal fisheries. This secured a minimum of cash income that constituted a small, but broadly spread domestic market, e.g., for household equipment such as stoves as well as for agricultural tools. Thus, the mechanical repair shops also produced equipment for rural households. Senghaas (1985) discusses the links between industrialization and the relatively egalitarian distribution of land and income (Norway had no significant feudal traditions), as well as to the quite strong political impact of local councils in rural areas. Independent smallholders gained democratic influence during the late nineteenth century. Murphy, Shleifer and Vishny (1989) argue that equality is one of the conditions for industrialization because the middle class, including farmers, is an important source for domestically produced manufactures.

Still, at this stage Norway, by several indicators, was a poor European country. At the turn of the century, Norwegian GDP per capita was below that of Denmark and Sweden and only about two-thirds of the average level of twelve western European countries according to Maddison (2003). ${ }^{7}$ Also Norwegian emigration per thousand people was high by European standards (Mjøset 1992: 64f). The country had a large raw material based export sector, largely owned by foreign capital, and there was widespread rural underemployment which spurred massive overseas emigration. But from this dismal starting point, Norway proved able to combine economic growth and social development also when the economy was exposed to the sudden emergence of two new energy sources: first hydropower, then oil. The exploration and utilization of these sources would, to some extent, become enclaves in the Norwegian economic structure, but despite this and other elements of foreign dependency, Norway did manage to secure additional development blocks related to water power and oil.8

In the twentieth century, another layer was added to the structure of the earlier century. This layer related to energy sources. It was also based on raw materials, but these were new discoveries, since their exploitation relied on technological breakthroughs: late in the nineteenth century chemical and electrical engineering opened up the generation and utilization of hydroelectricity from Norwegian waterfalls. In the early in the next century, foreign-based capital found Norway a profitable site for producing a variety of energy-intensive products such as artificial fertilizers, aluminium and zinc. These plants were located close to the hydropower plants, mostly in remote geographical locations.

7 See Table 1c in Maddison (2003). The Maddison-data are in 1990 international Geary-Khamis dollars and not directly comparable with those in Figure 1, which are in current prices (but in PPPs and relative to the OECD average).

8 Dahmén's (1950) notion of a development block can be briefly defined as the social networks involved in the extension of backwards and forwards linkages. Such blocks can be considered components of national innovation systems. 
Foreign ownership of modern manufacturing plants was widespread. Stonehill (1965) shows that nearly half of all traded stocks in manufacturing and mining firms in Norway in 1909 were owned by foreigners.9 At the time Norway was not only integrated in the world economy through trade in goods and services, but also in terms of capital flows.

Soon after complete independence from Sweden in 1905, nationalist business interests, farmers sceptical of industrialization and a social reform movement (people belonging mainly to the Liberal Party) hastily secured 'concession laws' that gave Norwegian authorities control over the relevant water resources (Lange 1977). These laws included provisions for joint ventures between national and foreign enterprises, clearly aimed at developing a Norwegian knowledge base for the relevant engineering supply industries. The manufacturing of turbines and machinery for power production became significant backward linkages in the water power block. In the postwar period, the manufacturing of components for automobile production developed as a forward linkage, an extension of Norway's aluminium production. In such ways, the export enclave developed ties with the rest of the economy. These linkages spread both the benefits and the costs of world market integration to large part of the economy and society.

In the interwar period, Norway-along with many European countries-experienced a period of social conflict. This period of unrest ended in the mid 1930s as labour and capital (unions and employer federations) settled on an agreement that regulated both wage bargaining and conflicts. Crucially, this mutual recognition linked wages to profits (i.e., world markets prices and productivity). The most influential union gained an important role to play in society. This started a long tradition of income policies that became a more important part of economic policies in Norway than in most other OECD economies. The set-up not only implied that incomes were negotiated among sections of the population, but also allowed the trade union movement to create its own income policies, linking pay in various sectors of the economy in such ways that secured remarkably stable sectoral pay differences. Within sectors, a policy of special pay increases for low-paid workers has made the wage distribution in Norway the most compressed one in the OECD.

We shall not discuss the development of the Norwegian welfare state here. Its features are in line with the other Nordic countries, cf., Esping-Andersen (1999), but until the 1990s, it was less comprehensive and less generous than in Sweden. This can partly be explained by the fact that incomes in Norway did not really reach the Swedish level until the 1980s. The welfare state is an important mechanism for distributing incomes in society. Unlike any other country that has discovered oil wealth, Norway had a modern welfare state in place before oil became important, and the welfare state became one of the institutions that secured broad distribution of the benefits from oil production.

We have so far agued that in spite of Norway's status as a dependent economy with a low per capita GDP level a hundred years ago, a nationally oriented and politically conscious bourgeois political elite-in the context of a quite egalitarian agrarian structure-managed to keep national control of natural resources vital to the economic development of the country. The social compromises of the 1930s paved the way for

9 Even as late as 1940, nearly a third of these stock were owned by foreigners. After the Second World War, all German owned stocks were confiscated by the government and foreign ownership was significantly reduced. 
income distribution mechanisms that linked the export enclave to the rest of the economy not just through forward and backward linkages. It also established the social democratic labour movement as a crucial collective actor in Norway's political economy. This social corporatist institutional set-up would suit the situation equally well after the discovery of a new natural resource. The idea of national control over resources was firmly rooted in society, and in the twentieth century, the state played a major role in this respect. There were mechanisms in place that could distribute the gains from oil, while at the same time preventing oil from destroying the fine tuned distribution of income that existed. ILO has again and again criticized the Norwegian government for limiting wage bargaining in the oil sector. However, this has not been a controversial decision in Norway. Rather, it is seen as a normal way of limiting bargaining power in a particular sector that otherwise might lead to more wage dispersion.

Before 1945, Denmark was clearly the Nordic country with the highest income. Norway's and Sweden's income levels were both roughly 20 per cent below the Danish level. According to the figures in Madison (2003), GDP per capita (in PPPs) in Norway was more or less around 90 per cent of the western European level for most of the twentieth century prior to 1970 . During the postwar years, Norway, along with many OECD countries, enjoyed, by historical standards, a 'golden age' of low unemployment, moderate inflation and rapid growth in incomes. Sweden was the most successful country in that period, catching up with Denmark around 1970. At that time, Norway was still behind (see Figure 1), but during the next decade, there was a 20 per cent increase compared to the OECD average. As noted, this catch-up process was parallel to the 1913-50 surge.

But Norway's new 'oil era' also implied a strengthening of historical patterns. The oil sector, namely, has important parallels to the earlier water power block. Oil and natural gas evidently increased the share of staple goods in total exports, reversing the 'golden age' trend towards a more diversified industrial structure. As in the earlier case of hydropower, the transition to an oil exporting economy initially implied high capital inflows and a large role for multinationals. Norway lacked the skills and technology necessary to develop the oil industry. As for institutional innovations, a main parallel to the early twentieth century concession laws was the founding of the Statoil Oil Company in 1972. This state-owned company played a crucial role as parts of Norwegian manufacturing industry were transformed into an engineering supply industry with specialized knowledge in the production of deep-sea oil drilling equipment, platforms, pipelines and supply ships. We return to this issue in section 6 .

Since the 1970s, the Norwegian economy has become even more internationally oriented than before, especially since oil is a global commodity rather than a regional or European one. Since 1980, oil exports have accounted for approximately a third of Norway's exports. During the 1990s, production increased to more than three million barrels per day, making Norway for some years the world's third largest exporter of crude oil. After 2000, crude production has declined while natural gas production has increased strongly. More recently the export share of petroleum products has increased to nearly a half of total exports, mainly due to high oil prices. 
Figure 2

Value added in the petroleum sector and petroleum rent, 1974-2006

$\%$ of GDP

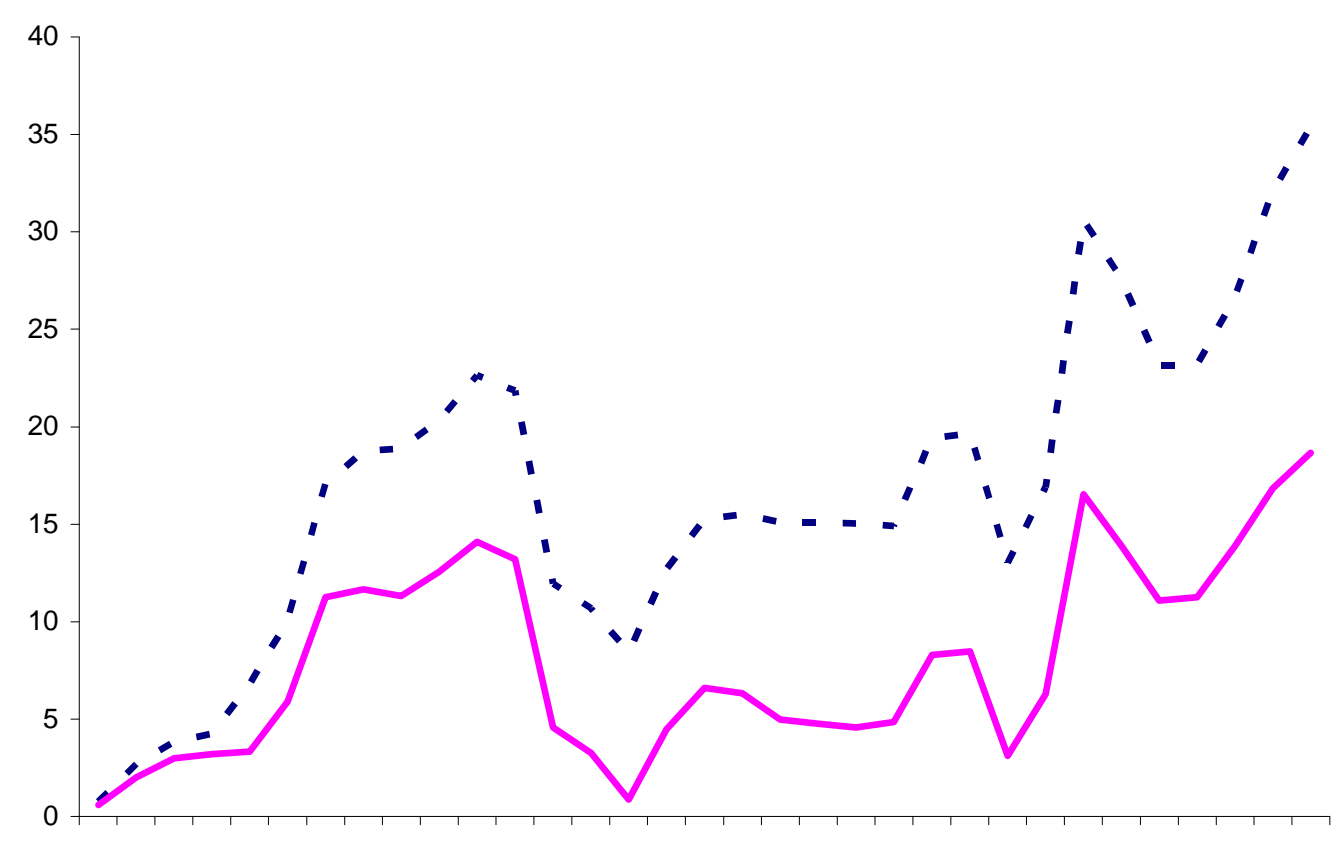

19741976197819801982198419861988199019921994199619982000200220042006

- - Value added petroleum sector

Petroleum rent

Source: Statistics Norway.

Figure 3

Current account surplus and net foreign assets, 1981-2006

$\%$ of GDP

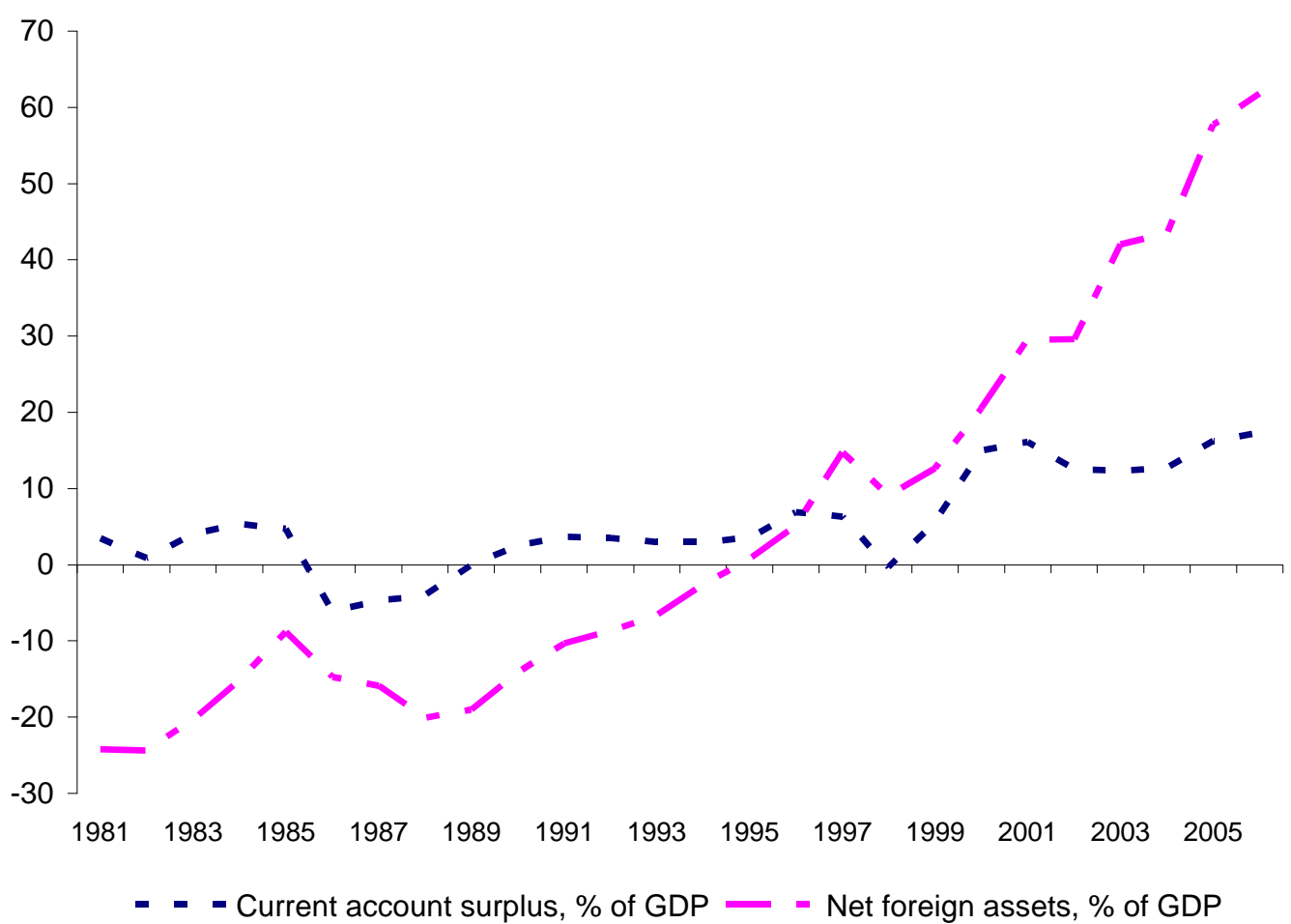

Source: Statistics Norway. 
As seen from Figure 2, much of the catch-up in the Norwegian GDP per capita can be traced back to the oil sector. Value added in this sector increased from zero to nearly 20 per cent of GDP by the early 1980s. Figure 2 also shows the petroleum rent as share of GDP.10 This rent is an estimate of how much of the Norwegian GDP is increased by excess profits in the petroleum sector compared to normal sectors of the economy.11 This measure does not take into account any spillovers from the petroleum sector to the rest of the economy, be it positive (knowledge spillovers) or negative (rent-seeking or Dutch disease). According to Figure 2, GDP per capita would have been roughly 5 per cent lower in the 1990s if there had been no petroleum rent, and since 2000, around 15 per cent lower. Combining these numbers with Figure 1, we suggest that the petroleum rent explains only a minor part of the relative increase in the Norwegian GDP per capita. According to Figure 1, by 2006 GDP per capita in Norway was roughly 70 per cent higher than the OECD average, of which less than 20 percentage points can be traced to the petroleum rent. As can be seen from Figure 3, the surplus on the current account in Norway as a share of GDP is roughly equal to the petroleum rent.

\section{Recent Norwegian economic policies}

A fixed exchange rate regime had been maintained during most of the postwar period, not only because it was the international norm, but also because it was a central component of the corporatist system developed since the 1930s. During most of that period, a system of credit controls was in place. Thus, the fixed exchange rate was easily maintained. When the system of credit rationing was dismantled from 1984 onwards, reaching full liberalization with all capital controls were lifted in 1991, the central bank defence of the external value of the currency rather had to rely on setting interest rates and on foreign currency market interventions. Wage negotiations were focused on maintaining competitiveness in the tradable goods sector and on maintaining a relatively egalitarian wage structure at the industry level. In periods of crisis, there were direct interventions in the bargaining process (in 1978/9 and 1988/9).12 Within this policy regime, the general aim of fiscal policies was to help maintain full employment. Norway has been one of the OECD countries recording the lowest unemployment rate and highest labour participation rate.

Discussions on how to develop a more robust policy in response to fluctuating oil prices led to the establishment of the Petroleum Fund in 1996. The Fund invests government oil revenues in international capital markets. Large current account surpluses (Figure 3) turned Norway into a major net capital exporter. This new feature has made the

10 Roughly speaking, the petroleum rent is an estimate of excess profits in the petroleum sector, i.e., that which emerges as excess operating surplus in the sector according to the national accounts when the factors of production in the sector have earned their normal returns.

11 In a resource-based economy, resource rents based on the exploitation of natural resources can be found in many sectors. In the Norwegian case, one would expect a rent to appear in fisheries and in hydropower production. In fisheries, the estimated rent is negligible and often negative. For the hydropower sector, there is now a positive rent, but only in the later years. Furthermore, the rent is small compared to the petroleum rent.

12 This kind of income policy has really never been used in Sweden. It was proposed by Mr Feldt, the minister of finance, during the Swedish crisis in 1990/1, but was turned down and Feldt resigned. 
economy more vulnerable to shocks originating in global financial markets. However, by enabling the country to separate exploration of oil from the use of oil revenues, the liberalization of international capital markets in recent decades has benefited Norway.

In the early 1990s, the Norwegian economy experienced unusually high unemployment and low economic growth, partly due to a severe banking crisis that followed the boom and financial deregulation of the mid-1980s. The dominating policy issue was how to restore full employment. A return to the devaluation policy of the previous decade was rejected, and while fiscal policies became more expansionary in line with traditional policy routines, budget deficits quickly became so large (although still small by international standards) that further stimuli were ruled out. Once again income policies were made the main ingredient of a new policy package. The so-called 'solidarity alternative' was an alternative to neoliberal deflation. It relied on the traditional corporatist formula whereby wage restraint would increase profitability in sectors exposed to foreign competition. That would improve the current account and allow fiscal policy to stimulate job creation while the fixed exchange band would secure an inflation rate in line with most European countries.

During the second half of the 1990s, the Norwegian economy showed rapid growth and gradually reached 'full employment' again. Price inflation was in line with trading partners and as oil prices increased, surpluses once again appeared in the current account as well as in government budgets. Figure 4 shows the exchange rate against the US dollar and the euro since 1980. Several large changes in the NOK/euro exchange rate can be related to changes in commodity prices. First, the depreciation of the krone in 1986 was partly a consequence of the falling oil price that preceded the May 1986

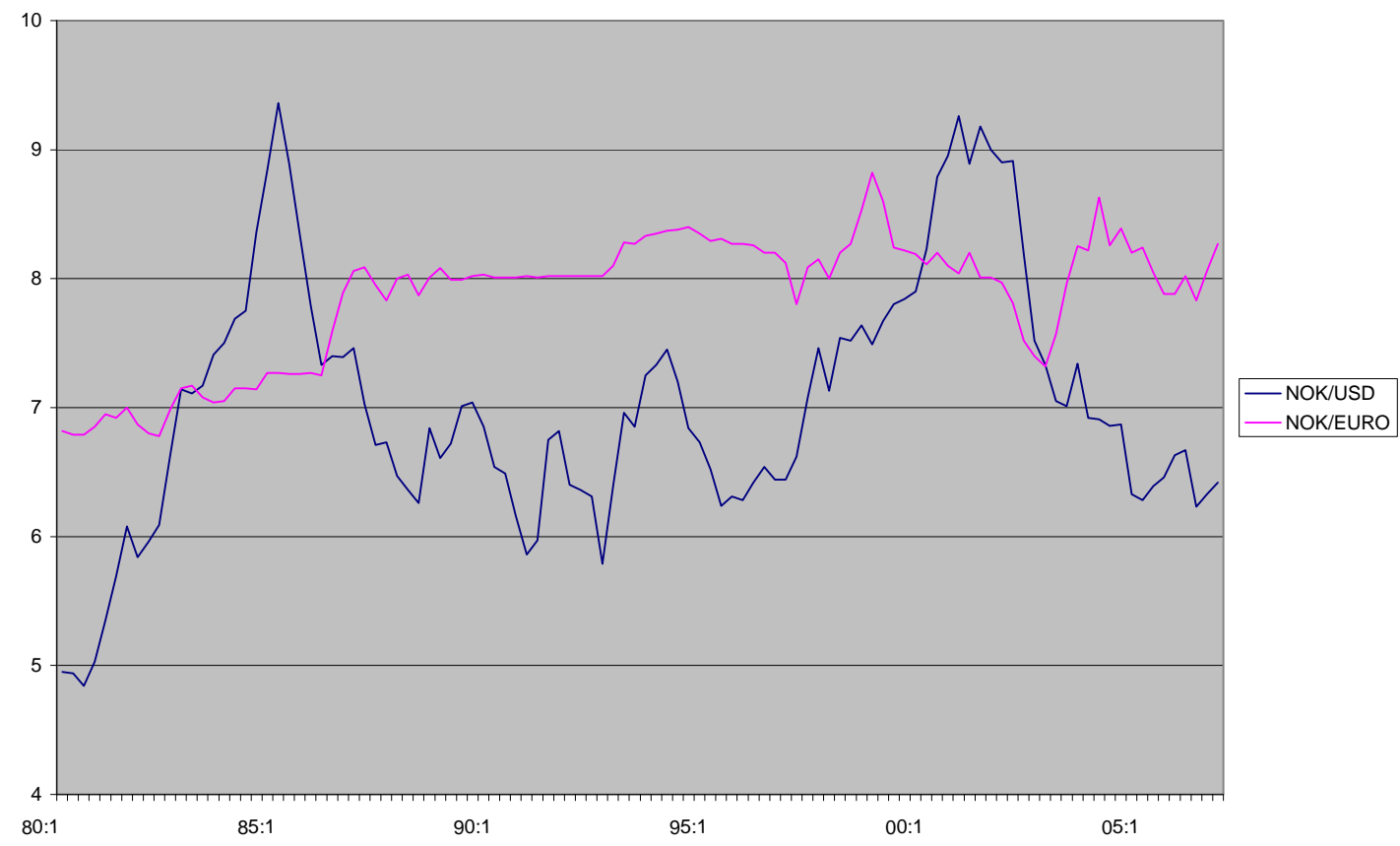

Source: Norges Bank (n.d.). 
devaluation. Due to the turmoil following the Asian crisis in 1997/8 and the low oil prices, the krone exchange rate was again hit, but only temporarily. The appreciation of the krone in 2002 and 2003 was, however, mainly due to the interest rate policy of the central bank after a turn to inflation targeting monetary policy in 2001.

On 29 March 2001, Norway, a country with one of the longest postwar commitments to a fixed (or 'stable') exchange rate formally abandoned that policy, opting for a floating exchange rate similar to that of Sweden and most Anglo-Saxon countries that had initiated this policy during the 1980s and 1990s.

The change to a floating rate and inflation targeting (formally in March 2001) was accompanied by other changes in government policy. In a government White Paper to the Storting, 13 the ministry of finance introduced two policy rules. The first, and perhaps the most important, was a fiscal policy rule that had no precedence in earlier documents. It stated that government revenues from petroleum (i.e., the various taxes on petroleum activities, as well as the profits from direct state ownership of petroleum resources) should be transferred to the Petroleum Fund. The Fund is allowed to invest only in foreign financial assets (shares and bonds). The expected real rate of return of these assets (estimated to be 4 per cent of the domestic value of the fund) is transferred to the annual state budget. The transfer may increase government spending or reduce taxes. This rule secures that petroleum wealth is not consumed but converted into financial wealth. With an ageing population, such wealth can help finance a generous welfare state in the future. Another purpose of the rule is to separate current petroleum revenues from the spending of these revenues, so that domestic spending does not vary with the highly fluctuating oil price. The long-run result of applying the rule should be the same as spending the permanent income from petroleum wealth. The idea was also that such a rule would contribute to a more stable industrial structure, since the tradable sectors would face more stable market conditions compared to a situation in which domestic spending was determined by current income. The aim was to avoid some aspects of the Dutch disease problem associated with a booming oil sector. At the time of the introduction of the fiscal rule, actual spending was close to the rule. Thus, its introduction did not lead to any noticeable fiscal stimuli. 14

The second policy rule was the explicit inflation target (2.5 per cent) for monetary policy. The ministry of finance recognized in the White Paper that the central bank's de facto conduct of monetary policy had already shifted its focus away from short-run exchange rate targeting. The ministry stated that it was better to establish an explicit target or anchor for monetary policy. Nevertheless, according to the ministry, the new monetary policy should support fiscal policy in stabilizing production and employment. Thus, it was claimed that the actual use of monetary policy instruments should not change even if the formal mandate had changed. The new mandate explicitly stated that

13 Guidelines for economic policy (St. meld. nr. 29 (2000-01) Retningslinjer for den økonomiske politikken).

14 When petroleum policy was discussed in 1974 in the first White Paper to parliament on this issue (St.meld.nr. 25 1973-74) the concern for the manufacturing sector and the policies to avoid the Dutch disease were first formulated, the conclusion was to avoid exploring too much of the resource in order to limit both the resource movement effect and the spending effect, cf., the discussion in section 4 below. Note that at this time capital markets were not liberalized. Therefore, the possibility of separating current oil revenues from budgetary policies was not discussed. 
the bank should aim at a stable value of the krone both domestically (i.e., low inflation) and in international markets (i.e., the exchange rate). But the krone should also be floating. How can two targets be achieved using only one policy instrument, the interest rate? According to the ministry of finance, this is possible because a small open economy is unlikely to maintain an inflation rate similar to that of its main trading partners without a fairly stable exchange rate between these countries. This position is, of course, simply a restatement of the traditional Scandinavian model of inflation, the traditional backbone of Norwegian macroeconomic policy analysis since the 1960s, cf., Aukrust (1977).

In sum, we argue that economic openness as such, and sudden resource riches more specifically, do not necessarily affect economic and social development negatively. We have shown that under Norway's twentieth-century conditions, it has been possible to obtain high growth, equality and social development in spite of the country being a raw materials exporter, very open to both trade, and lately also to international factor mobility. Perhaps the analysis of development failures should not ignore the nature of specific, historically established conditions of national economic and social development?

\section{A review of the resource curse and Dutch disease arguments}

The resource curse modelling tradition was introduced in section 2. This literature finds that resource abundant countries are 'cursed' both in terms of the level of income and the growth in income, cf., Sachs and Warner (2001). Not only do rich countries often lack an abundance of natural resources, but fast growing countries are also resource poor. Such conclusions emerge from simple correlations between growth performance up to 1990 and the share of exports of natural resource-based commodities to GDP, as well as from econometric growth studies that control for a number of other variables that are generally accepted to stimulate economic growth, cf., Sachs and Warner (1999). Mehlum, Moene and Torvik (2006) use the same data, showing that with a slightly more general model-specification of the effects of institutional quality, the negative effects of resource abundance are modified. For countries with 'good institutions' there is no resource curse at all, but there are no beneficial effects of resource abundance on growth either.

Economists generally argue that a greater supply of all factors of production benefits the society. Natural resources, however, are held to be a curse, not a blessing! Taking this claim literally, one might easily jump to the conclusion that if a country discovers a natural resource such as oil, its government should refrain from exploring it! One should even keep companies or government bodies from undertaking surveys to map the natural resource status of a country, since this might later lead to exploration and consequently lower growth and incomes. Geological surveys should simply be forbidden, existing ones should be closed down. Although these policy prescriptions are not suggested by anyone, they follow logically from the resource curse literature. If we believe in this conclusion, Norway should not even be considered as a possible success model!

Two main arguments have been suggested in order to explain the effects of resource abundance on economic growth. The first one is a purely economic one, usually related 
to the notion of a 'Dutch disease', cf., van Wijnbergen (1984). A resource boom generates not only macroeconomic disturbances, but also affects a country's industry composition. This boom is decomposed into a resource movement effect and a spending effect. The first effect is due to the shift of resources in the economy away from the production of traded goods and into extraction of the natural resource. If labour is immobile between countries, the traded goods sectors will face stronger competition on the labour market and wages rise. By assumption, non-traded goods sectors can increase their prices when costs go up, while this is impossible for traded goods sectors. These latter therefore reduce supply. Thus, the resource movement effect crowds out exports of traditional tradables.

The spending effect relates to the spending (by government or others) of the rent from the resource extraction activities. Even if income is spent on both traded and non-traded goods, the production of traded goods in small open economies is not determined by domestic demand but by supply conditions. In order to produce more non-traded goods to meet increased demand, wages are bid upwards and supply of traded goods is reduced. Therefore resource booms are often associated with de-industrialization, since manufacturing sectors are usually regarded as the most important traded goods producers. De-industrialization follows if macroeconomic policies respond to a resource boom by allowing more spending. The background is that in most resource abundant countries, the government receives a large share of the resource rent either directly through ownership of the resources or through taxation.

Gylfason (2001: 851) claims that 'Norway's oil exports have crowded out its non-oil exports krone by krone, leaving total exports stagnant relative to national income for a generation'. Looking at Figure 3 we can see that his statement is clearly rejected by more recent data. Norway was already a very open economy by 1900 with a high export share so the small increase in this share has hardly been important for growth in Norway during the twentieth century. The alleged Dutch disease concerns a change in industry composition, and de-industrialization more specifically. It is assumed that the manufacturing sector is characterized by learning-by-doing that is external to firms but present at the national level. If the manufacturing sector shrinks due to the resource boom, there will be fewer positive spillover effects from R\&D and other types of learning. Growth will be negatively affected. This emphasis on national level manufacturing skills converges with our own emphasis, but the interpretation is overly restrictive. Senghaas (1985) relies on Hirschman's (1977) specification of a 'staple goods theory of economic growth' by means of the notion of linkages, indicating that in the early European developers (the Nordic countries included) and in type (1) countries, the positive spillovers from resource-based industries may be as extensive as those from manufacturing industries.

The argument that raw materials are inferior to manufacturing industry (in terms of linkages) partly reflected the specific historical and institutional context of Latin American (type (2)) attempts-unsuccessful, by the way-at import-substitution in the 1950s. In other structural and institutional contexts (e.g., type (1)), however, the growing share of staple exports also stimulates upgrading of the manufacturing sector. Deliveries may first be to domestic exploration activities, but later, the new skills may give rise to new export products.

In the Latin American 1950s arguments, it was expected that raw materials would imply a terms of trade loss relative to manufacturing exports. In recent empirical studies of 
economic growth, one has attempted to include changes in the terms of trade in growth equations. The argument is that volatility is generally harmful to growth because it creates instability, increasing the kind of risks that affect investors negatively. The results in Sachs and Warner (2001) indicate that an improvement in the terms of trade stimulates growth, but the interpretation of the result is not obvious as it is not reasonable to assume that terms of trade are exogenous to the economy.

The other main argument for the resource curse focuses more on the interaction between economics and politics. Rents following from the exploitation of many resources often end up as government revenue. Nearly 90 per cent of Norway's petroleum rent (cf., Figure 2) is estimated to end up as government revenue. The argument is that 'easy' money distorts governmental decisionmaking. Several arguments are waged as to why politically motivated allocations affect economic growth negatively. One is that because of the income effect of the rent, citizens and politicians are not investing enough resources into innovation, R\&D and education. Gylfason (2001) shows that countries with much natural capital invest less in education. Thereby, according to Gylfason, natural capital crowds out human capital with detrimental effects on growth and incomes in the long run. But he acknowledges that Norway does not fit this picture well.

The second politically related argument is that natural resource abundance stimulates rent-seeking activities relative to production activities. The extent to which people turn their attention to 'grabbing' parts of the rent rather than to production activities, depends on the institutional qualities of the country. Mehlum, Moene and Torvik (2006) associate these qualities with the absence of corruption, as well as with the presence of bureaucratic efficiency, transparency of government and private accounting practices, rule of law, etc. It is not clear whether large resource rents lead to a decline in institutional quality, but there is empirical evidence indicating that growth is affected in resource abundant countries with low institutional quality. Following the presentation of a model of grabbing activities where the success of those activities depends on institutional quality, they show empirically (using cross-country data) that the negative effect of resource abundance on growth vanishes in countries with high institutional quality such as Norway and most other OECD countries. We shall investigate the robustness of their findings in section 6.

A third line of politically oriented arguments is related to government decisions. One main argument (cf., Auty 2001) is that resource abundant countries are less likely to follow an open economy approach, i.e., that they are more likely to favour trade restriction. The reason given is that resource abundance makes it possible to rely less on other tradable goods producers, favouring instead domestic production that is sheltered from import competition. Another argument is that resource rents that end up as government revenues lead to unsustainable budgetary behaviour. If a negative price shock hits the economy, large deficits appear. Because it is hard for the government to return to sustainable fiscal balances, private savings are crowded out. This is probably a good description of what took place in many oil-producing countries, after the price collapse during the winter of 1985/6. Norway had turbulent times following this shock, but recorded fiscal deficits only in 1992/3, and these were not large by international standards.

The general problem of this literature is its inclination to explain and draw policy conclusions from mechanisms that cover all cases. Thus, mechanisms that may be 
wholly or partly relevant to types (2)-(5) are mostly not relevant to the case of Norway. As already noted, the Norwegian case is closer to type (1). We now turn to some cases in this group.

\section{How natural resources can be an advantage}

In economic history, the standard view of the resource curse has been challenged with reference to specific cases. A set of particularly interesting arguments has been drawn from type (1), the westernized settler colonies. Wright emphasizes that resource abundance cannot be seen as an exogenously given geological endowment, cf., Wright (1990); David and Wright (1997); Wright and Czelusta (2004); see also Maloney (2002). Many resource-based economies have developed poorly due to mismanagement of their mineral potential through inappropriate policies. With reference to Maddison's (2003) figures, Wright notes that the US overtook the UK around the turn of the previous century, just at the time when the US was the world's dominant producer of virtually every major industrial mineral of that era. Wright's view is that the abundance of minerals in the US was not mainly due to fortunate natural endowments. Rather, the abundance should be seen as a form of collective learning, a return on large-scale investment in exploration, technological development and innovations in mineral extraction, refining and so forth.

David and Wright (1997) attribute the rise of American minerals to three factors: favourable legal environment, investments in the infrastructure of public knowledge (such as geological surveys) and education in mining, minerals and metallurgy. Wright also points out that Australia, which earlier had very high levels of GDP per capita, was not able to grow in line with the US at this time. He holds that this was due to lack of appropriate mineral policies, not to less natural resource abundance per se. Furthermore, the Australians tended to favour a less outwards-oriented economic policy that limited the exports of minerals and thereby reduced the growth of the mining sector. When a more export-oriented policy was introduced in the 1960s, rapid growth of mining sector took place. 15

Wright and Czelusta (2003) argue that the American petroleum sector developed successfully because it was transformed into a knowledge industry: a development block entailing institutional relationships among government agencies, academic institutions and private corporations. Major breakthroughs for petroleum geology took place in California during the first decades of the previous century. They relied on surveys and maps from US Geological Survey. Thus resources were not primarily a matter of endowments, but of learning. In this way, California became the world's first oil driven economy with an expanding, not a contracting, manufacturing sector.

15 Many, but not all economists will appreciate the quote (Wright and Czelusta 2003: 11) brings from a geological mission to the Cape York Peninsula where large outbreaks of bauxite were discovered in 1955. The geologist H. Evans wrote: 'As the journey down the coast revealed miles of bauxite cliffs, I kept thinking that, if all this is bauxite, then there must be something wrong with it; otherwise it would have been discovered and appreciated long ago'. There was nothing wrong with it, and in 1964 the area held about one-quarter of the known potential bauxite in the world. 
The development of Norway's oil industry fits this account (Wright and Czelusta 2003). The government focused on technology transfers from foreign companies (Andersen 1993). It established a state-owned company in 1972. One of Statoil's main tasks was to organize learning and technology transfers. A separate government body or directorate was set up to implement part of government policy in the area. Some universities developed their education and research in areas relevant for the petroleum sector. Government policies were in place to ensure that linkages could develop between petroleum extraction and the supply industry.

As the new manufacturing skills spread, Statoil would place orders with a variety of old and new Norwegian firms. Crisis-ridden shipyards were restructured into producers of oil-exploration equipment. Partly due to natural trade barriers and the need to develop maritime oil platforms that could be used in rough waters, Norwegian industry developed production technologies which later turned out to be quite competitive. During the early 1990s, Norway's non-membership relation to the EU was reorganized in connection with the European Economic Area. As a result, all non-tariff barriers in the form of more or less hidden arrangements (there were no formal trade barriers such as tariffs or quotas) had to be lifted, exposing Norway's various oil-related industries fully to foreign competition. In this way, the initial infant industry policy was dismantled after two decades. Under both these trade regimes, markets for manufacturing goods were developed that partially halted the decline-i.e., the 'Dutch disease effects' of oil-in Norwegian manufacturing.

Note that the institutions relevant for this industrial change are those institutions that developmental states (cf., section 2) nourish in order to reap benefits for the whole nation from their natural riches. The institutions referred to in Mehlum, Moene and Torvik's (2006) revised resource curse arguments are different ones.16 We now take a closer look at their study.

\section{Cross-country growth equations on resource abundance and institutions}

This section has a limited purpose. We investigate the robustness of the results arrived at in the studies by Sachs and Warner (1999) and Mehlum, Moene and Torvik (2006) with regard to the effect of natural resources on economic growth. We use the crosssection data reported in Table 4 of Mehlum, Moene and Torvik (2006), but exclude African countries, mainly in order to limit the heterogeneity of our country sample. The basic model in Sachs and Warner (1999) states that growth in per capita GDP (growth) depends on the initial income level per capita (initial income), the degree of openness of the economy (openness), the investment ratio in GDP (investment), a measure of institutional quality (institutional quality), and finally on resource abundance measured as the share of exports of primary goods in GDP (resource abundance). Mehlum, Moene and Torvik (2006) include an interaction term between institutional quality and resource abundance which is simply the product of the two variables (interaction). They find that this interaction term is highly significant and robust across specifications,

16 Their measure is an unweighted average of five indexes from Political Risk Services, indicating rule of law, bureaucratic quality, corruption in government, risk of expropriation and government repudiation of contracts. These indexes indicate properties of a nightwatchman state. 
concluding that the resource curse is mainly a problem for countries with poor institutional qualities, which is in line with other studies, cf., Auty (2001).

Table 2 presents some results from estimating this growth model using cross-country data. Column (1) is an attempt to replicate regression 2 of Table 2 in Mehlum, Moene and Torvik (2006). The results are qualitatively similar but not identical.17 We focus on the effects of the resource abundance variable and note that the estimate for the effect of resource abundance is similar but of opposite sign to the estimate of the interaction effect. This is the main finding in Mehlum, Moene and Torvik (2006) and supports their theoretical set-up. The negative effect of resource abundance is counteracted in countries with good institutions that block 'grabbing' but promote productive activities. Note also that the variable institutional quality is not significant in this specification. It follows that institutional quality matters for growth only if a country is at least to some extent resource based. Institutional quality per se does not seem to matter much for growth. Many students of economic growth and institutions will be puzzled by this conclusion.

Tests for the residuals in the model in column (1) reject normality and heteroscedasticity so standard t-tests are not valid. In order to get residuals that are closer to white noise we introduce dummies. We add three regional dummies for East Asian countries, Latin America and other non-OECD countries while the old OECD countries (excluding Japan and Turkey) belong to the reference group. This is also an attempt to control for possible left-out regressors in the model. Since we have

Table 2

Regression results (endogenous variable is growth in per capita GDP, 1960-90)

\begin{tabular}{lcc}
\hline & $(1)$ & $(2)$ \\
\hline Constant & 12.16 & 10.17 \\
& $(6.17)$ & $-18)$ \\
Initial income & -1.87 & -1.48 \\
& $(-7.63)$ & $(-7.18)$ \\
Openness & 1.42 & 1.27 \\
Resource abundance & $(3.31)$ & $(3.74)$ \\
& -12.13 & -14.00 \\
Institutional quality & $(-3.36)$ & $(-4.90)$ \\
& 1.75 & 0.47 \\
Investments & $(1.25)$ & $(0.41)$ \\
Interaction term & 1.62 & 1.32 \\
& $(3.57)$ & $(3.67)$ \\
Regional dummies & 12.14 & 18.47 \\
Observations & $(1.96)$ & $(3.69)$ \\
Adj. R & No & Yes \\
Marginal resource effect on growth in Norway & 59 & 59 \\
\hline
\end{tabular}

Note: Estimated t-values in parentheses.

17 We have used the data in Table 4 of Mehlum, Moene and Torvik (2006) and tried three estimation packages (TSP, TROLL, and PcGive) all of which gave identical results, but slightly different from their results. They are not using the log of the investment rate and it is not clear to us whether this is intentional. Sachs and Warner (1999) use the log of the investment rate as we do in Table 1. 
only one observation per country, we cannot use a fixed effects model which would have been preferable. It turned out that only the dummy for East Asian countries was significantly different from zero, so this is the only dummy we include in the model in column (2). Now the residual tests show that normality is not rejected and neither is the homoscedasticity test. Compared to column (1), estimates in column (2) show a clear shift in the relative size of the two parameters of interest. The resource abundance coefficient increases in absolute size somewhat from the previous estimate. But the interaction term increases much more in size. There is now a quite strong positive effect of resource abundance on growth if institutions are quite good. All the old OECD countries (except Greece) show a high score on institutional quality. According to these results, they benefit from resource abundance. As one can see from the table, the institutional quality variable is significant when interacted with the resource variable. A fairly robust conclusion is therefore that institutional quality taken separately does not matter much for economic growth; it only matters when interacted with resources. 18

The bottom line of Table 2 shows the growth effect of a marginal increase in resources for Norway, as implied by the various regressions. The figures are determined as the estimated coefficient for resource abundance plus the estimated interaction effect times the value of institutional quality of Norway which is 0.96 . For the whole sample (including Africa), Mehlum, Moene and Torvik (2006) find a threshold level of 0.93 for the institutional variable if resource abundance is to have either a negative or positive effect on growth. The estimates for Norway given in Table 2 vary a lot between the two models, but the most reliable model in a statistical sense (column (2)) indicates that resource abundance has a large and positive marginal effect on growth in Norway. 19

Another sensitivity test of the resource curse model is to ask if the statistical models work well as used for predicting future growth as opposed to in sample fit. We have done this for Norway using data only for the period from 1990 to 2006.20 The main change in variables is that the resource-abundance variable increases to 0.18 due to the influence of petroleum exports, initial income has increased to its level in 1990 and the investments ratio has dropped to slightly less than 20 per cent in that period. GDP growth per capita dropped from 3 to 2.5 per cent as an annual average from 1990 to 2006. The model in column (1) estimates growth at 1.5 per cent, which is clearly an underestimation compared to actual outcome. In other words, the model overestimates the negative effects of resource abundance in the Norwegian case (cf., the bottom line of Table 2).

18 When included separately institutional quality enters with a negative estimate in their preferred specification, cf., Mehlum, Moene and Torvik (2006: Table 1, regression (4)).

19 We have also estimated the model using the Autometrics algoritm in PcGive using the 'dummy saturation' technique, cf., Doornik and Hendry (2007). The result with regard to the marginal effect of institutional quality is very similar to that of the model in column 2 in Table 2. These results are available upon request.

20 One should also note that in 1990 the Norwegian economy was in a severe recession, while in 2006 it was close to a cyclical peak. 


\section{Conclusions}

Our analysis provides some lessons that might be worth considering for economies that are rich in natural resources. They are based on our study of the Norwegian case and on our critical assessment of the resource curse literature.

\section{Management of natural resources}

Partly for historical reasons, but also due to conscious political decisions, the Norwegian government has extensively controlled the management of natural resources. This has been the case with the two energy resources of the twentieth century (waterfalls and oil), but also with 'older' resources such as the fishery resources at sea. Management of resources-in terms of collecting information about their size and change, how to organize exploration and control the production of both renewable and non-renewable resources - is vital if economic benefits are to be harvested on a sustainable basis. There have been policy errors in Norway on several occasions, but there has also been policy learning that has led, over time, to improved resource management.

\section{Who shall earn the rents from natural resource exploitation?}

Gradually it has become an accepted policy in Norway that the central government should be the major benefactor of rents. This is partly so because the resources fundamentally belong to the whole nation and not to any private company or group of people. In some sectors such as the fisheries, the rent is basically distributed to the producers in the sector, and little if anything is taxed as rents that end up as government revenue. In contrast, for hydropower production and petroleum extraction, a major part of the rent is taxed by the government. Because natural resources are immobile, they constitute an ideal form of government revenue with little deadweight loss. Funding government expenditures by rents or by capital income from financial investments based on these rents will improve economic efficiency compared to alternative sources of financing. This will clearly benefit the long-term financing of the Norwegian welfare state.

\section{Creating linkages between natural resource extraction and the rest of the economy}

Fisheries, forestry, hydropower generation and later petroleum exploration have been integrated with the rest of the Norwegian economy through forward and backward linkages. Forward linkages have led to industrial development connected to the production of semi-manufactured goods (canning industry, paper and pulp, metal products and chemical products). Backward linkages have implied the development of manufacturing production of capital equipment (shipping industry, turbines, transmitting equipment, as well as oil rigs, seismic instruments and so forth). The state's own activities have even implied fiscal linkages. Although there clearly have been periods of de-industrialization due to the growth of the resource-based industries, these industries have also been instrumental in stimulating the advancement of manufacturing in certain areas. There is really no reason why resource extraction per se cannot lead to the development of a manufacturing sector that is characterized by learning, spillovers and the scale economies that are usually considered the core of a modern knowledge economy. In Norway, active industrial policies have been an important element in the creation of these linkages. 


\section{Creating buffer funds to hedge against terms of trade shocks that resource-based}

economies are more prone to be subjected to

One drawback often mentioned in connection with a large share of resource-based industries and exports, is that they may create large fluctuations in the economy due to volatile prices. This volatility may increase uncertainty and lead to lower investment and growth. This may spill over to financial markets and the exchange rate may also be affected, making the conduct of monetary policy more difficult. We have many examples of such episodes in the Norwegian economy. The last one was perhaps the turmoil following the Asian crisis in 1997/8 when oil prices fell to around 10 dollars per barrel and the resource rent was very low. The traditional way to counteract such price fluctuations has been to spread the risk somewhat by means of a framework for income settlements and wage negotiations. As Katzenstein (1985) shows, such corporatist institutions are typical of most small, open, western economies. Such institutions have even evolved in some of the famous catch-up processes by latecomers within OECD, cf., Mjøset (1987) for Finland, and Mjøset (1992) for Ireland. Another response is to create a financial buffer fund so that one separates the short-run link between revenues and expenditures. Large changes in revenues may lead to unsustainable fiscal policies by the government. Later, these must be adjusted through austerity programmes that lead the economy into a durable slump. Several OPEC countries had to go through such a phase after the good years (high oil price) of the mid-1980s. Norway also experienced several years of spending cuts and tax-increases in the wake of the plummeting oil price during the winter of 1985/6. Norway's petroleum fund was established in the wake of this experience of instability. The creation of this fund has clearly benefited policies and thus also the economy during the last decade.

\section{A non-renewable resource is only partly produced -it is also an asset}

Renewable resources can be expected to yield returns permanently if properly managed. This is not the case with a non-renewable resource such as petroleum. In Norway, it has always been a recognized fact that at some stage there would be no more oil to exploit profitably. Even if resources prove to be much larger than initially estimated, politicians must take the resource limits into account. The value of the unexploited petroleum still in the ground can be calculated using standard estimation methods. The future price and costs of production are highly uncertain, but it is possible to estimate the permanent income from the resource. Norway has gradually moved away from spending the permanent income of the resource to spending only the income from a financial fund financed by accumulated resource incomes. The idea behind the fiscal policy rule introduced in 2001 was that spending the expected returns from a financial fund would give a much more stable fiscal policy than one that was more strongly influenced by current prices, since the latter affects, to a large degree, expectations of future prices.

\section{Institutional factors are probably important for managing and benefiting from resource abundance}

Theoretical arguments and empirical evidence suggest that institutional factors are important for growth and this applies to resource abundant countries in particular, cf., Mehlum, Moene and Torvik (2006). Although a variable capturing the rule of law (the indicator often used in empirical studies) clearly is relevant for growth, we believe that institutions, which are important for making natural resources a blessing and not a curse for a country, deserve a closer study. They probably include institutions that are more 
specific for the resource-based industries than what is usually included as proxies in econometric studies, cf., Wright and Czelusta (2004).

As already indicated, we have some reservations about the extent to which other units can draw policy lessons from the recent experience of Norway. The wider the gap between Norway's socio-institutional framework and that of the unit assumed to gain from policy learning, the more careful one should be about direct transfers. More indirect policy learning may still be possible, but that presupposes a thorough analysis of the situation on the 'receiving' side. This is why further development of taxonomies mapping various types of development experiences is important for interdisciplinary development research.

\section{References}

Andersen, S. S. (1993). The Struggle over North Sea Oil and Gas: Government Strategies in Denmark, Britain and Norway. Oslo: Scandinavian University Press.

Aukrust, O. (1977). 'Inflation in the Open Economy. A Norwegian Model'. In L. B. Krause and W. S. Salant (eds), Worldwide Inflation: Theory and Recent Experience. Washington, DC: The Brookings Institution, 107-53

Auty, R. M. (2001). 'The Political Economy of Resource-Driven Growth'. European Economic Review, 45 (4-6): 839-46.

Dahmén, E. (1950). Svensk industriell företagarverksamhet. Kausalanalys av den industriella utvecklingen 1919-1939. Stockholm: IUI.

David, P. A., and G. Wright (1997). 'Increasing Returns and the Genesis of American Resource Abundance’. Industrial and Corporate Change, 6 (2): 203-45.

Doornik, J. A., and D. F. Hendry (2007). Empirical Econometric Modelling - PcGive 12, vol. 1. London: Timberlake Consultants Ltd.

Esping-Andersen, G. (1999). Social Foundations of Postindustrial Economies. Oxford: Oxford University Press.

Evans, P. (1995). Embedded Autonomy. Princeton: Princeton University Press.

Evans, P., and J. E. Rauch (1999). 'Bureaucracy and Growth: A Cross-National Analysis of the Effects of "Weberian" State Structures on Economic Growth'. American Sociological Review, 64 (5): 748-65.

Gylfason, T. (2001). 'Natural Resources, Education, and Economic Development'. European Economic Review, 45 (4-6): 847-59.

Hall, P., and D. Soskice (2001). Varieties of Capitalism. Oxford: Oxford University Press.

Hirschman, A. O. (1958). The Strategy of Economic Development. Chicago: University of Chicago Press.

Hirschman, A. O. (1977). 'A Generalized Linkage Approach to Development with Special Reference to Staples'. Economic Development and Cultural Change, 25, (Supplement): 67-98. 
Kasa, S., and L. Mjøset (2001). 'The Environmental Problems of the Classical International Division of Labour’. Sosiologisk Tidsskrift, 9 (1-2): 107-34.

Katzenstein, P. (1985). Small States in World Markets. Ithaca: Cornell University Press.

Lange, E. (1977). 'The Concession Laws of 1906-09 and Norwegian Industrial Development'. Scandinavian Journal of History, 2 (4): 319-33.

Lange, E. (1989). 'Industrien bak det moderne Norge'. In E. Lange (ed.), Teknologi i virksomhet. Oslo: Ad Notam, 11-32.

Maddison, A. (2003). The World Economy: Historical Statistics. Paris: OECD.

Maloney, W. F. (2002). 'Missed Opportunities, Innovation and Resource-Based Growth in Latin America'. WB Policy Research Working Paper 2935. Washington, DC: World Bank.

Mehlum, H., K. Moene, and R. Torvik (2006). 'Institutions and the Resource Curse'. The Economic Journal, 116 (508): 1-20.

Mjøset, L. (1987). 'Nordic Economic Policies in the 1970s and 1980s'. International Organization, 41 (3): 403-56.

Mjøset, L. (1992). The Irish Economy in a Comparative Institutional Perspective. Dublin: National Economic and Social Council.

Mjøset, L. (2006). ‘The Study of Nordic Varieties of Capitalism'. Economic Sociology: The European Electronic Newsletter, 8 (1): 4-11.

Mjøset, L. (2007). 'An Early Approach to the Varieties of World Capitalism: Methodological and Substantive Lessons from the Senghaas/Menzel-Project'. Comparative Social Research, 24: 123-76.

Mjøset, L., and T. H. Clausen (2007). 'An Introduction to the Comparison of Capitalisms’. Comparative Social Research, 24: 1-17.

Murphy, R., A. Shleifer, and R. Vishny (1989). 'Income Distribution, Market Size and Industrialization’. Quarterly Journal of Economics, 104: 537-64.

Norges Bank (Central Bank of Norway) (n.d.). Available at: www.regjeringen.no/en/dep/fin/The-Ministry/Related-Institutions/Central-Bank-ofNorway.html?id=213276

OECD (2008). National Accounts database. Available at: www.esds.ac.uk /international/support/user_guides/oecd/na.asp

(The) PRS Group (Political Risk Services) (n.d.). Available at: www.prsgroup.com/ .

Pontusson, J. (2005). Inequality and Prosperity: Social Europe vs. Liberal America. Ithaca: Cornell University Press.

Sachs, J. D., and A. M. Warner (1999). 'Natural Resource Abundance and Economic Growth’. NBER Working Paper 5398. Cambridge, MA: National Bureau of Economic Research.

Sachs, J. D., and A. M. Warner (2001). 'The Curse of Natural Resources'. European Economic Review, 45 (4-6): 827-38.

Senghaas, D. (1985). The European Experience. A Historical Critique of Development Theory. Leamington Spa: Berg Publishing.

Statistics Norway (n.d.). Statistics Norway. Oslo. Available at: www.ssb.no/en/. 
Stonehill, A. (1965). 'Foreign Ownership in Norwegian Enterprises'. Social and Economic Studies No. 14. Oslo: Statistics Norway.

UNDP (2008). 'Human Development Indices: A Statistical Update 2008 - HDI Rankings’ Available at: undp.org.

van Wijnbergen, S. (1984). 'The “Dutch Disease”: A Disease after all?'. The Economic Journal, 94 (373): 41-55.

Wright, G., and J. Czelusta (2003). 'Mineral Resources and Economic Development'. Berkeley: Stanford University. Mimeo.

Wright, G., and J. Czelusta (2004). 'The Myth of the Resource Curse'. Challenge, 47 (2): 6-38. 